\title{
SOSIALISASI PENYULUHAN PENCEGAHAN PENYEBARAN VIRUS COVID 19
}

\author{
${ }^{1 *}$ Condro Endang Werdiningsih, ${ }^{2}$ Lambok Simamora, ${ }^{3}$ Achiruddin \\ Universitas Indraprasta PGRI, Jakarta, Indonesia \\ Email : "endangcondro4@gmail.com
}

Manuskrip: Desember -2021; Ditinjau: Desember -2021; Diterima: Desember -2021; Online: Januari-2022; Diterbitkan: Januari-2022

\begin{abstract}
ABSTRAK
Tujuan kegiatan ini adalah memberikan pengetahuan kepada perangkat RT di lingkungan Rw 011 melalui sosialisasi tentang pencegahan penularan Covid -19 di Perumahan Anyelir 3 Kelurahan Kalimulya Depok diharapkan agar masyarakat sadar dan paham tentang Covid -19 , bertambah disiplin dalam menjalankan penerapan protocol kesehatan serta bijak dan teliti memilih sumber informasi yaitu diambil dari lembaga resmi atau berita terpercaya yang melalui verifikasi sehingga terhindar dari stress dan tetap optimis dengan melakukan aktifitas sehari-hari. Isi waktu luang dengan kegiatan yang positif. Metode pelaksanaan untuk mencapai tujuan dari pengabdian masyarakat ini dalam mengatasi masalah masyarakat dalam pencegahan penularan Covid 19 maka yang dilakukan oleh Tim Pengabdi adalah melalui sosialisasi pencegahan penularan Covid 19 dan pembagian hand sanitizer, dan poster, di masjid yang berada di Kelurahan Kalimulya Depok. Sosialisasi dilakukan kepada masyarakat dalam rangka membantu masyarakat untuk membiasakan diri menghadapi kondisi ini. Sosialisasi juga dilakukan untuk memberikan informasi guna meningkatkan pemahaman masyarakat saat menghadapi penyebaran virus Covid -19, diharapkan masyarakat mematuhi protokol kesehatan yang berlaku karena sejatinya Covid-19 belum hilang dan masih menjadi pandemi di dunia. Hasil yang dicapai dalam pelaksanaan pengabdian masyarakat ini adalah Warga rw 011 untuk "tidak abai" menjalankan protocol kesehatan dalam pecegahan penyebaran virus Covid -19 dan untuk "tidak lebay" terhadap fenomena infodemik seputar Covid -19 serta pembuatan tulisan berupa Artikel Ilmiah dalam bentuk prosiding maupun Jurnal.
\end{abstract}

\section{Kata Kunci: Virus, Pencegahan, Covid 19}

\section{PENDAHULUAN}

Pada Desember 2019, diberitakan bahwa kasus pneumonia misterius pertama kali dilaporkan di Wuhan, Provinsi Hubei. Sumberpenularan kasus ini masih belum diketahui pasti, tetapi kasus pertamadikaitkan dengan pasar ikan di Wuhan. Sejak kasus pertama di Wuhan,terjadi peningkatan kasus COVID-19 di China setiap hari dan memuncak diantara akhir Januari hingga awal Februari 2020. Awalnya 
kebanyakan laporan datang dari Hubei dan provinsi disekitar, kemudian bertambah hingga ke provinsi-provinsi lain dan seluruh China.

Fakta ini juga dikemukakan dalam data WHObahwa di awal tahun 2020 digemparkan oleh merebaknya virus baru yaitu coronavirus jenis baru Severe Acute Respiratory Syndrome (SARS-Covid-19) dan penyakitnya disebut Coronavirus Disease (COVID-19) yang berasal dari Wuhan, Tiongkok pada akhirDesember 2019 dan sampai saat ini sudah 65 negara sudah terjangkitvirus ini. Menurut Riedel dkk (2019:617-22) Coronavirus adalah virus RNA dengan ukuran partikel 120-160 $\mathrm{nm}$. Virus ini utamanya menginfeksi hewan, termasuk di antaranya adalah kelelawar dan unta.Sebelum terjadinya wabah COVID-19, ada 6 jenis coronavirus yang dapat menginfeksi manusia, yaitu alphacoronavirus 229E, alphacoronavirus NL63, betacoronavirus OC43, betacoronavirus HKU1, Severe Acute Respiratory Illness Coronavirus (SARS-CoV), dan Middle East Respiratory Syndrome Coronavirus (MERS-CoV). (Yuliana, 2020)

Akibat berkembangnya wabah Corona Virus Disease-19 (COVID-19) di dunia dan akhirnya ke sejumlah wilayah di Indonesiapada bulan Maret 2020, tentu sangat mengkhawatirkan seluruh lapisanmasyarakat termasuk penyebarannya telah ditemukan di Propinsi Jawa Barat. Khususnya, Kota Depok hingga kini masih berstatus sebagai wilayah zona merah dengan total laporan kasus positif Covid-19 tertinggi di Jawa Barat dan wilayah Bodetabek berdasarkan lamanresmi masingmasing pemerintah kota.

Dalam menangani penyebaran Covid-19 maka perlu dilakukan upaya preventif pada masyarakat. Hasil penelitian (Sari \& Sholihah'Atiqoh, 2020) menyatakan bahwa ada hubungan antara pengetahuan masyarakat dengan kepatuhan penggunaan masker sebagai upaya pencegahan penyakit Covid-19 Sejalan dengan hasil penelitian tersebut, maka diperlukan adanya upaya edukasi bagi masyarakat terkait pencegahan Covid-19 di antaranya melalui kebiasaan menggunakan masker. Salah satu cara preventif yaitu dengan melakukan kegiatan promosi kesehatan yang dilakukan melalui sosialisasi, edukasi, dan penggunaan berbagai media informasi untuk memberikan terkait bahaya dan penularan Covid-19. (Kemenkes RI, 2020) (Putri, 2020)

Berbagai media informasi yang digunakan dapat berupa luring dan daring. Sebagaimana di masa pandemi ini, masyarakat cenderung mudah mengakses informasi secara daring. Hal ini menjadi salah satu peluang untuk melakukan sosialisasi tentang bahaya Covid-19 dan pencegahannya. Promosi kesehatan berbasis daring tentang protokol Covid-19 dapat memberikan pengetahuan dan menumbuhkan kesadaran bagi masyarakat untuk menerapkan protokol kesehatan sebagai upaya mencegah COVID-19. (Suhadi et al., n.d.)

Meskipun sudah memasuki kondisi new normal, wabah ini tetap harus diwaspadai. Sebab, menurut PDI (Yuliana, 2020) telah terjadi tranmisi pada virus covid-19, virus ini masuk melalui saluran pernapasan atas kemudian bereplikasi di sel epitel saluran nafas atas (melakukan siklus hidupnya). Setelah itu dapat disertai dengan sesak memberat, fatigue, myalgia, gejala gastrointestinal seperti diare dan 
gejala saluran nafas lain. Setengah dari pasien timbul sesak dalam satu minggu. Dan pada kasus berat perburukan secara tepat dan progresif, metabolic sulit dikoreksi dan terjadinya pendarahan atau disfungsi system koagulasi dalam beberapa hari. Pada beberapa pasien, gejala yang muncul ringan, bahkan tidak disertai demam.

Dalam tatanan kehidupan baru atau kenormalan baru yang harus dijalani dengan baik, taat pada protokol kesehatan yang diisyaratkan pemerintah. Sebab, menurut detik.healthy.com bahwa penyebaran virus corona bisa ditularkan melalui 1) droplet saat seseorang batuk, bersin atau melakukan hal yang mengeluarkan udaraatau partikel kecil melalui hidung dan mulut dalam jarak dekat, 2) udara, virus corona menyebar melalui partikel kecil yang melayang diudara, 3) permukaan yang terkontaminasi, virus bisa terkontaminasi melalui batuk atau bersin lalu berindah ke hidung, mulut, atau mata,4) tempat yang rawan penyebaran virus seperti tempat yang ramai, sempit dan ruangan yang terbatas dan tertutup. Sehingga dalam menghadapi kondisi new normal, perilaku dan tindakan masyarakat harus berubah total dari tindakan biasa ke yang sering di lakukan

Kompas.com bahwa penerapan protocol kesehatan covid -19 yang harus ditaati masyarakat sebagai berikut :

1) jaga kebersihan tangan, bisa mencuci tangan di air mengalir atau menggunakan handsanitizer

2) jangan menyentuh wajah,

3) Terapkan etika batuk dan bersin, caranya dengan menutup ,ulut dan hidung menggunakan lengan atas bagian dalam

4) Menggunakan masker, kenakan masker medis kemanapun saat keluar rumah atau berinteraksi dengan orang lain

5) Jaga jarak, senantiasa menjaga jarak dengan orang minimal 1 meter

6) Isolasi mandiri, dilakukan jika tubuh kita tidak sehat seperti mengalami batuk, pilek, demam , nyeri tenggorokan, sesak nafas, diminta untuk secara sadar dan sukarela melakukan isolasi mandiri di dalam rumah.

7) Jaga kesehatan, pastikan kesahatan fisik tetap terjaga dengan makan makanan yang bergizi , berjemur dan olagraga. Hal ini sesuai dengan himbauan dari pemerintah terkait perubahan prilaku yang harus dilakukan, namun nampaknya tidak mempengaruhi semua orang secara merata.

Lingkungan RW 11 kelurahan kalimulya, Cilodong memiliki 10 RT dengan jumlah 682 kepala keluarga (KK) khususnya Perumahan Anyelir 3 Kalimulya sudah menerapkan penangan dalam pencegahan virus Covid -19 seperti pembatasan ketat area keluar masuk komplek, kemudian semua warga yang pulang ke rumah dicek suhu tubuhnya dan disemprotkan desinfektan. Sehingga dapat dikatakan perumahan Anyelir 3 Kalimulya "tidak abai" dalam menghadapi penyebaran virus Covid -19. Namun, bukan hanya saja kesehatan jasmani yang diperhatikan melainkan kesehatan psikologi atau jiwa perlu diperhatikan juga. Kesehatan psikologi bisa saja terganggu misalnya stress berlebihan. Stress berlebihan bisa saja terjadi dikala pandemi Covid -19 sebab banyak hoaks-hoaks yang beredar dimasyarakat dan pengetahuan yang kurang ditambah lagi memiliki kepribadian pencemas. Dampak yang timbul akibat dari stress yang berlebihan yaitu kurang 
istirahat, system imun menurun, takut untuk melakukan sesuatu seperti berobat jika sakit, kurang produktif dan lain-lain. Melihat keadaan ini, kelompok kami bergerak untuk melaksanakan kegiatan pengabdian kepada masyarakat agar masyarakat tetap "tidak abai" dan "tidak lebai" dalam menghadapi kondisi new normal tentang pencegahan Covid-19 melalui edukasi tentang sosialisasi pencegahan penularan di pengurusan Rt pada lingkungan Rw 011 melalui meeting zoom. Di lingkungan RW 11 kelurahan kalimulya, Cilodong memiliki 10 RT dengan jumlah 682 kepala keluarga (KK).

\section{METODE}

Pelaksanaan kegiatan sosialisasi penyuluhan pencegahan Penyebaran Virus Covid-19 dilakukan dengan metode :

1. Ceramah

yaitu menjelaskan pengertian pemahaman masyarakat saat menghadapi penyebaran virus Covid -19, diharapkan masyarakat mematuhi protokol kesehatan yang berlaku karena sejatinya Covid-19 belum hilang dan masih menjadi pandemi di dunia.

2. Demonstrasi, yaitu memberikan demonstrasi bagaimana cara-cara melakukan Cuci tangan menggunakan handsanitizer yang benar dan langkah-langkah cuci tangan yang tepat

\section{HASIL DAN PEMBAHASAN}

Kegiatan pengabdian masyarakat ini diawali dengan mendatangi lokasi kegiatan yaitu di Perumahan Anyelir 3 Kalimulya Depok Jawa Barat. Hasil wawancara dengan Ketua Rukun Warga 011 Kalimulya yaitu Achiruddin, bahwa dia berharap dengan adanya penyuluhan tentang pencegahan penyebaran virus Covid 19 di Pengurus Rw 011 Perumahan Anyelir 3 Kalimulya Depok Jawa Barat dalam mengenal lebih dalam pentingnya disiplin menjalankan protocol kesehatan. Dengan penyuluhan yang kami berikan kita akan bersama-sama mulai dari tahap awal hingga sampai para pengurus RT (Rt 01-10) dapat memahami maksud penyuluhan yang diberikan oleh tim abdimas dari Unindra. Dan juga dengan adanya penyuluhan ini diharapkan bisa membantu kepengurusan Rt di Lingkungan RW 011 dalam mensosialisasikan warganya untuk "tidak abai" dalam menghadapi penyebaran virus Covid -19. Selain kesehatan jasmani yang diperhatikan, kesehatan psikologi atau jiwa juga perlu diperhatikan. Kesehatan psikologi bisa saja terganggu misalnya stress berlebihan. 


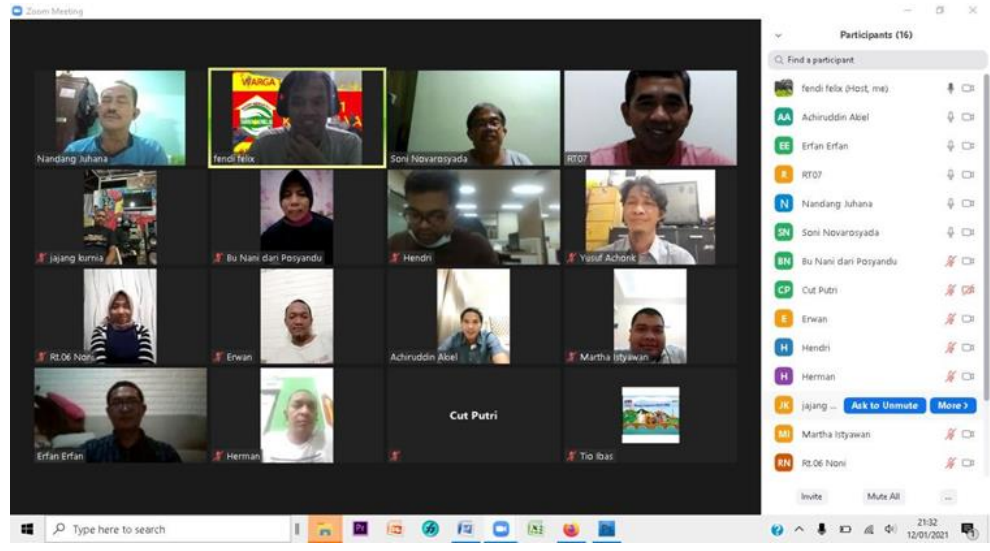

Gambar 1. Ceramah secara Daring

Stress berlebihan bisa saja terjadi dikala pandemi Covid-19 sebab banyak hoaks-hoaks yang beredar dimasyarakat dan pengetahuan yang kurang ditambah lagi memiliki kepribadian pencemas. Dampak yang timbul akibat dari stress yang berlebihan yaitu kurang istirahat, system imun menurun, takut untuk melakukan sesuatu seperti berobat jika sakit, kurang produktif dan lain-lain. Melihat keadaan ini, kelompok kami bergerak untuk melaksanakan kegiatan pengabdian kepada masyarakat agar masyarakat tetap "tidak abai" dan "tidak lebai" dalam menghadapi kondisi new normal tentang pencegahan Covid-19 melalui edukasi tentang sosialisasi pencegahan penularan di pengurusan Rt pada lingkungan Rw 011 melalui meeting zoom.

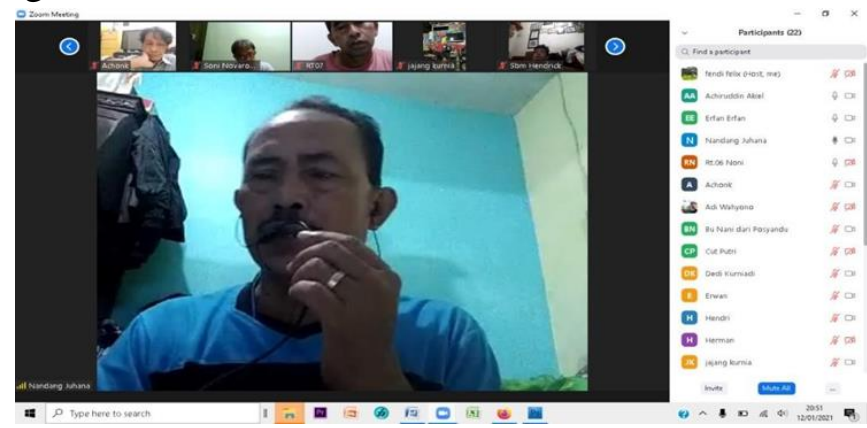

Gambar 2. Lurah Kalimulya Kota Depok

Dalam pelaksanaan pengabdian kepada masyarakat di Kepengurusan RT di Lingkungan RW 011 untuk mencapai tujuan dari pengabdian masyarakat ini dalam mengatasi masalah masyarakat dalam pencegahan penularan Covid 19 maka yang dilakukan oleh Tim Pengabdi adalah melalui sosialisasi pencegahan penularan Covid 19 dan pembagian hand sanitizer, dan poster, di masjid yang berada di Kelurahan Kalimulya Depok. Sosialisasi dilakukan kepada masyarakat dalam rangka membantu masyarakat untuk membiasakan diri menghadapi kondisi ini. Sosialisasi juga dilakukan untuk memberikan informasi guna meningkatkan pemahaman masyarakat saat menghadapi penyebaran virus Covid -19, diharapkan masyarakat mematuhi protokol kesehatan yang berlaku karena sejatinya Covid-19 belum hilang dan masih menjadi pandemi di dunia 


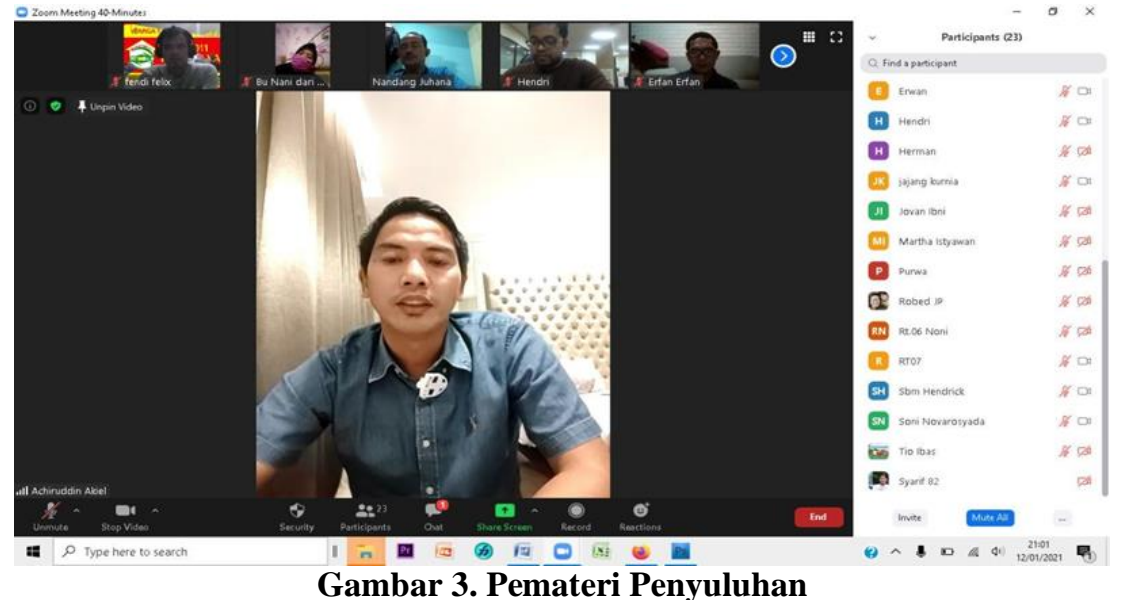

\section{KESIMPULAN}

Peserta penyuluhan yaitu Rt 01-010 di RW 011 di Perumahan Anyelir 3 Kalimulya Depok sangat antusias mengikuti kegiatan pengabdian masyarakat. Penerapan protocol kesehatan di Lingkungan RW 011 khususnya rt 01-10 menjadi makin disiplin dalam 3M yaitu mencuci tangan dengan sabun dan air mengalir, menjaga jarak minimal 1 meter dan menggunakan masker jika keluar rumah. Lingkungan RW 11 kelurahan kalimulya, Cilodong memiliki 10 RT dengan jumlah 682 kepala keluarga (KK) khususnya Perumahan Anyelir 3 Kalimulya tetap menerapkan penangan dalam pencegahan virus Covid -19 seperti pembatasan ketat area keluar masuk komplek, kemudian semua warga yang pulang ke rumah dicek suhu tubuhnya dan disemprotkan desinfektan. Lingkungan RW 11 khususnya Rt 01- 010 dengan masyarakatnya menjadi lebih bijak dan teliti memilih sumber informasi dengan memilih informasi dari lembaga resmi atau berita terpercaya yang melalui verifikasi dan memeriksa kebenaran informasi yang didapat dari media sosial kemudian tidak sembarang menyebarluaskan informasi bila belum ada bukti jelas atau rujukan resmi. Lingkungan RW 11 khususnya Rt 01- 010 sudah mulai memahami langkah-langkah apa yang dilakukan jika ada warganya yang terkena Covid -19. Lingkungan RW 11 khususnya Rt 01- 010 sudah mulai memahami bagaimana protocol isolasi mandiri dilaksanakan. Lingkungan RW 11 khususnya pengurus Rt 01- 010 dengan masyarakatnya menjadi "tidak abai" dan "tidak lebai" dalam menghadapi kondisi new normal tentang pencegahan Covid-19 Lingkungan RW 11 khususnya pengurus Rt 01- 010 dengan masyarakatnya mampu memahami kondisi isolasi mandiri dari berbagai aspek seperti salah satunya adalah aspek sosial kemasyarakatan, dimana keluarga yang melakukan isolasi mandiri tidak boleh keluar rumah ataupun menerim tamu sehingga kebutuhan atau keperluan keluarga tersebut harus dibantu oleh masyarakat atau tetangga sekitarnya tanpa kontak langsung. Lingkungan RW 11 khususnya pengurus Rt 01- 010 mampu memahami pentingnya pembentukan Satgas Covid 19 dan tugas- tugas Satgas Covid 19. 


\section{DAFTAR PUSTAKA}

Andarsyah, R., Prianto, C., \& Hanum, N. (2020). Pemberian Bantuan Langsung Terkait Pandemi Covid-19 Di Desa Cigugur Parongpong. Merpati, 2(1), 510.

Caesaron, D., Salma, S. A., Prasetio, M. D., \& Rifai, M. H. (2021). Edukasi dan Sosialisasi Pencegahan dan Pengendalian COVID-19 melalui Media Poster di Desa Bojongsoang, Kabupaten Bandung. Abdimas: Jurnal Pengabdian Masyarakat Universitas Merdeka Malang, 6(2), 221-229.

Haikal, H., et al. (2021). Penyuluhan Pemanfaatan Media Sosial Bagi Perkembangan Sumber Daya Manusia (SDM) Pada Masyarakat Desa. Jurnal PADMA: Pengabdian Dharma Masyarakat, 1(3).

Jawetz, E., Melnick, J. L., \& Adelberg, E. A. (2001). Jawetz, melnick, Adelberg's Medical microbiology.

Putri, R. N. (2020). Indonesia dalam menghadapi pandemi Covid-19. Jurnal Ilmiah Universitas Batanghari Jambi, 20(2), 705-709.

RI, K. (2020). Kemenkes Ri.

Russell, C. D., Millar, J. E., \& Baillie, J. K. (2020). Clinical evidence does not support corticosteroid treatment for 2019-nCoV lung injury. The Lancet, 395(10223), 473-475.

Sari, D. P., \& Sholihah'Atiqoh, N. (2020). Hubungan antara pengetahuan masyarakat dengan kepatuhan penggunaan masker sebagai upaya pencegahan penyakit Covid-19 di Ngronggah. Infokes: Jurnal Ilmiah Rekam Medis Dan Informatika Kesehatan, 10(1), 52-55.

Sinaga, L. R. V., Munthe, S. A., \& Bangun, H. A. (2020). Sosialisasi perilaku cuci tangan pakai sabun di desa sawo sebagai-bentuk kepedulian terhadap masyarakat ditengah mewabahnya virus covid-19. Jurnal Abdimas Mutiara, 1(2), 19-28.

Suhadi, S., Nurmaladewi, N., Yasnani, Y., \& Tina, L. (n.d.). Promosi Kesehatan Berbasis Daring Mengenai Perilaku Pencegahan Covid-19 Bagi Masyarakat Kota Kendari. Anoa: Jurnal Pengabdian Masyarakat Sosial, Politik, Budaya, Hukum. Ekonomi, 1(3), 245-255.

Yuliana, Y. (2020). Corona virus diseases (Covid-19): Sebuah tinjauan literatur. Wellness And Healthy Magazine, 2(1), 187-192. 